\title{
Macroeconomic Approach of the Determinants of Stock Price Movements in Jordan
}

\author{
Imad Zeyad Ramadan \\ Full Prof., Department of Finance, \\ Applied Science Privet University, P.O. Box 166, Amman, Jordan \\ E-mail: i_ramadan@asu.edu.jo
}

Received: Nov. 23, 2015 Accepted: August 10, $2016 \quad$ Published: December 1, 2016

doi:10.5296/ajfa.v8i2.8616 URL: http://dx.doi.org/10.5296/ajfa.v8i2.8616

\begin{abstract}
This study aimed to test the effect of macroeconomic factors on the movements of stock prices of Jordanian industrial companies listed in Amman Stock Exchange (ASE) in order to provide empirical evidence about the determinants of the movements of stock prices. To achieve this objective, all the 77 Jordanian industrial firms listed at ASE for fifteen years from 2000 to 2014 have been selected, resulting in 1054 firm-year observations. The unbalanced pooled cross-sectional time series multiple least square regression method has been used to present data analysis. while the experiential results showed significant negative effect of two of the macroeconomic factors, namely, interest and inflation rates, on the movements of the Jordanian industrial companies stock prices, results found that the effect of money supply and GDP on the movements of stock prices were significantly positive. These results are consistent with (Mukherjee and Naka, 1995, Zhao, 1999 \& Udegbunam and Eriki, 2001, Al-Qenae, Li \& Wearing, 2002, Dimitrios Tsoukalas, 2003 , Ibrahim 2003; Chaudhuri and Smiles, 2004)
\end{abstract}

Keywords: Macroeconomic factors; Stock price movements; Jordan 


\section{Introduction}

Capital markets play a vital and important role in the economy by providing funding necessary for the growth of the economy all over the world. They are more than just a place for securities trading, where they are considered as a channel for fast and easy transition among savers who have a surplus of money and investors who have a need for money. A study carried out by (Udegbunam and Erkki, 2001) has concluded that the capital markets are necessary for economic growth because they ensure the transmission of resources to the most productive investment opportunities. ( Guglielmo et al. (2004) have concluded that the basic feature of capital markets, which gives their significance, is that such markets set prices and increase the liquidity of financial instruments that are traded, as well as they distribute risks, which encourage the reduction of investment costs and thus contribute to economic growth on the long term.

The movement of stock prices in the financial markets is one of the few financial phenomena that have received considerable attention from all subspecialties in the financial field, as it is apparent that there is a growing rejection of the efficient market theory in pilot research carried out by the researchers. The ideas related to market speculation are revived in order to explain the volatile nature of the capital market; and the future solely remains able to prove whether the current financial crisis will lead to an intellectual revolution that leads to the development of a coherent theory of the behavior of the capital market to be an alternative to Market Efficiency Theory.

Under a free economy, the economists suggest that commodity prices are determined by the forces of demand and supply, without going into the details of the factors that influence these forces. In the stock market, pilot studies - conducted on the market value of companies - have concluded that the stock price is greatly affected by a number of factors that affect the value of the company such as the carrying value of the company, profit distribution policy, earnings per share, price earnings ratio and dividend cover ratio (Gompers, Ishii \& Metrick, 2003). Therefore, it is normal to conclude that a large part of the movement in stock prices is caused by investors' revision to their expectations of future cash flows.

The factors that lead to movement of stock prices have become a major concern to academic researchers and investors alike. While a small number of researchers have studied the factors affecting the movement of stock prices at microeconomic level, also few researchers have studied these factors at macroeconomic level.

Few studies in Jordan have tried to study the factors affecting the movements of stock prices for example (Faris, 2010) which concluded that there was a statistically significant positive relationship between the market stock price, net asset value per share; market price of stock dividend percentage and GDP, and also there was a statistically significant inverse relationship with inflation and interest rate. It should be noted that the study of (Faris ,2010) has been performed on the Jordanian banking sector only, without addressing other sectors. At the State level, the studies that have examined the factors affecting the movement of stock prices have concluded discrepant results, although there is some consensus on some of these factors in all countries, and the reason for this is the different circumstances that surround 
each state in terms of laws, specificities of the country, type of investors and other factors that characterize each country. Thus, the main objective of this study is to provide quantitative evidence on the factors that determine the stock price movements in Jordan. The importance of this study lies in that Jordan has become increasingly investment destination for most Arab financial investors as a result of the events witnessed by other Arab countries and the reforms in the financial sector witnessed by Jordan.

\section{Literature Review}

All empirical evidences that linked the development of the financial markets and economic growth of the state have concluded the existence of a statistically significant positive impact for the development of financial markets on economy.

A study carried out by Levine and Zervos (1998) has concluded that the various measurements of the activity of financial markets are linked by a statistically significant positive relationship with different real economic measures of growth in different countries, and that this relationship is strongest in developing countries. This study has also concluded that subsequent to controlling for initial conditions and financial and political variables, the different measures of the development of financial markets are strongly linked by a statistically significant relationship to current and future rates of economic growth and productivity.

Schwert (1989), Kostoulas and Kryzanowski (1996), and Maysam and Koh (2000) have concluded that the movements of stock prices can be understood through the study of macroeconomic variables. While the relationship between the stock market and economic activities is completely clear regardless of the direction of the relationship, but there is no agreement on a common set of macroeconomic variables that have an impact on the stock market activities whereas macroeconomic variables that were examined as determinants of the movements of stock prices showed different results through pilot studies.

Ibrahim and Aziz (2003), Booth and Booth (1997), Wongbangpo and Sharma (2002), Chen (2003), Chen et al. (2005), Maysami and Koh (2000), and Mukherjee and Naka (1995) have concluded that rates of inflation, prevailing interest rates, rates of growth of money supply, size of reserves, local currency exchange rates and productivity of the sector are all considered as statistically significant determinants of stock prices movements.

Not macroeconomic variables alone that have an impact on the stock markets, as monetary policy also plays an important role in influencing the share prices in capital markets. For example, raising interest and discount rates reduces the current value of future cash flows, which would reduce the value of stock returns, and therefore the decline in stock prices. According to the substitution effect hypothesis, the increase in prevailing interest rates in the market increases the opportunity for cash alternative costs, and later to affect substitution between interest securities, as this hypothesis indicates the existence of an inverse relationship between interest rates and capital market returns.

Chen et al. (2005) concluded that the interest rates had no impact on the movements of stock prices. The reason for this was suggested by (Mukherjee and Naka 1995) that the change in 
interest rates on short-term and long-term will affect -and in the same direction - the discount rates.

With regard to inflation, Asprem (1989) concluded that inflation is linked by a positive relationship with stock returns, but pilot studies such as Barrows and Naka (1994), Chen et al. (1986) and Chen et al. (2005) have concluded that the negative inflation rates are associated by a statistically significant negative relationship with the capital market returns, so that, and within normal circumstances, the increase in inflation rates will lead to strict monetary policy, which would have a negative impact on stock prices.

Experimental studies on the effect of exchange rates on the movements of stock prices showed conflicting results. Aggrawal (1981) concluded the existence of a statistically significant direct effect for exchange rates on stock prices. In contrast, ( Soenen and Hennigar,1988) have concluded that the relationship between exchange rates and stock prices is a statistically significant inverse relationship. But (Ibrahim ,2000) concluded that in the long term there will not be a relationship between exchange rates and stock prices.

A study carried out by (Wohar \& Mark, 2006) has concluded that stock prices are very sensitive to expectations about future earnings and dividend distributions growth. Cochrane (1992) and Timmerman (1995) have concluded that fluctuation in stock prices can be attributed to change in dividend growth rates and earnings growth rates associated with stock. Cochrane (1992) concluded that earnings distributions growth is more influential on the stock prices than its effect on company's profits. Corwin (2003) concluded that uncertainty and asymmetric information have a strong statistically significant impact on the movement of stock prices.

In light of what has been previously mentioned, many microeconomic and macroeconomic factors have an impact on stock prices in the stock market, but the effect varies depending on the company, sector, economy and time, but it can be concluded that most factors have the same behavior regardless of time, sector or company. For example, increased inflation and interest rates, low profits, lower dividend rates and mismanagement have negative effects on stock prices and vice versa.

\section{Data and Methodology}

The econometric methodology, mainly the Multi-linear regression model has been utilized in this study following Koutsoyianis (1977) who is stated that the advantage of this approach is its hypothetical believability, logical capacity, precision of parameter gauges. The necessary financial data for this study has been obtained from the Amman Stock Exchange (ASE) site and from the Central Bank of Jordan (CBJ).

\subsection{Dependent Variable}

The dependent variable is the market value of the stocks prices (MSP) of Jordanian industrial companies listed on the Amman Stock Exchange for the time period of 2000 to 2014.It should be noted that the last trading day of each year of the study has been used as proxy of the stock prices movements. 


\subsection{Independent Variables}

Four independent variables, most of the previous studies were unanimous that have an impact on the movements of stock prices, were selected to express macroeconomic variables as follows:

- Interest rate (INT)

- Money Supply (MS)

- Inflation rate (INF), and

- Gross Domestic Product (GDP) of Jordan.

Three more control variables were used in the econometric model for the study, related to the specific characteristics of the firm, to control the expected relationship between macroeconomic factors and the movements of stock prices in the Jordanian market as follows:

- $\quad$ Net Asset Value per Share (NAPS)

- $\quad$ Dividend payout ratio (DPR), and

- $\quad$ Earnings per Share (EPS).

\subsection{The Econometric Model}

Proceeding from the goal that the study seeks to achieve, the movements of the stock prices in the Jordanian market in the econometric model of the study can be seen as follows:

$$
M S P=f(I N T, M S, I N F, G D P)
$$

The econometric model in $\mathrm{Eq}(1)$ can re-formulate mathematically as follows:

$$
M S P_{i t}=\alpha+\beta_{1} I N T+\beta_{2} M S+\beta_{3} I N F+\beta_{4} G D P+\varepsilon
$$

Where; $M S P_{i t}$ is the last trading day of each year of the study as proxy of the stock prices movements. it are the $i^{\text {th }}$ cross-sectional company for the $t^{\text {th }}$ period, as $\mathrm{i}=1,2,3, \ldots, 77, \mathrm{t}$ $=1,2,3, \ldots, 15 ; \alpha$ is a constant; $\beta^{\prime}$ s unknown parameters to be estimated; $I N T, M S, I N F$ and GDP are the macroeconomic factors; $\varepsilon$ is the random error.

Because the specific characteristics of the firm might affect the market value, as found in many of the empirical studies, three control variables i.e., Net Asset Value per Share (NAPS), Dividend payout ratio (DPR), and Earnings per Share (EPS) are added, and the econometric model is modified as follows:

$$
\begin{gathered}
M S P_{i t}=\alpha+\beta_{1} I N T+\beta_{2} M S+\beta_{3} I N F+\beta_{4} G D P+\beta_{5} N A P S_{i t}+\beta_{6} D P R_{i t}+\beta_{7} E P S_{i t} \\
+\varepsilon
\end{gathered}
$$

Where; it are the $i^{\text {th }}$ cross-sectional company for the $t^{t h}$ period, as $\mathrm{i}=1,2,3, \ldots, 77, \mathrm{t}=$ $1,2,3, \ldots, 15 ; \beta^{\prime}$ s are unknown parameters to be estimated; NAPS, DPR and EPS are the control variables. 


\section{The Results of Regression Analysis}

Table 1 shows the results of the regression analysis based on two models: in model 1 the $M S P$ is regressed on INT, MS, INFand GDP in the absence of the control variables. Table 1 also shows that $M S P$ is affected significantly negatively by one of the macroeconomic factors namely, the interest rate and is affected significantly positively by Gross Domestic Product while the money supply and the inflation rate shows no significant effect on the stock price movement. Also model 1 in table 1 shows that the Adj. R-square is 0.449 while the F-value is 215.277 indicating that the model can explain almost 45 percent of the stock price movements and the macroeconomic factors can play an important role in determining the share price movement in the Jordanian financial market.

In model 2, after adding the control variables, one can notice that the explanatory power of the model has improved almost 31 percent from 0.449 to 0.589 indicating that model 2 is the right model to explain the stock price movement in the Jordanian stock market. Model 2 in table 1has suggested that the Jordanian stock prices MSP are affected significantly by the macroeconomic factors utilized in the study, and while the interest rate and the inflation rate have a significant negative effect on the stock prices, and the money supply and gross domestic product positively affect the stock prices. 
Table 1. Regression analysis; Dependent variable MSP

The

\begin{tabular}{|c|c|c|c|c|}
\hline \multirow{2}{*}{ Variable } & \multicolumn{2}{|c|}{ Model 1} & \multicolumn{2}{|c|}{ Model 2} \\
\hline & Coefficient & t- value & Coefficient & $\mathrm{t}$ - value \\
\hline Constant & 12.254 & & 0.094 & \\
\hline INT & -0.025 & $8.610^{* *}$ & -0.262 & $3.746^{* *}$ \\
\hline MS & 0.021 & 1.287 & 0.108 & $2.519^{*}$ \\
\hline INF & -0.712 & 1.369 & -0.552 & $2.738^{*}$ \\
\hline GDP & 0.752 & $3.229^{*}$ & 0.570 & $2.406^{*}$ \\
\hline NAPS & & & 0.848 & $3.312^{*}$ \\
\hline DPR & & & 0.672 & $2.382^{*}$ \\
\hline EPS & & & 0.653 & $4.785^{* *}$ \\
\hline R-Square & \multicolumn{2}{|c|}{0.452} & \multicolumn{2}{|c|}{0.592} \\
\hline Adjusted R-Square & \multicolumn{2}{|c|}{0.449} & \multicolumn{2}{|c|}{0.589} \\
\hline df Regression & \multicolumn{2}{|c|}{4} & \multicolumn{2}{|c|}{7} \\
\hline Residual & \multicolumn{2}{|c|}{1049} & \multicolumn{2}{|c|}{1046} \\
\hline Total & \multicolumn{2}{|c|}{1053} & \multicolumn{2}{|c|}{1053} \\
\hline $\mathrm{F}$ & \multicolumn{2}{|c|}{215.277} & \multicolumn{2}{|c|}{216.61} \\
\hline Sig. & \multicolumn{2}{|c|}{0.000} & \multicolumn{2}{|c|}{0.000} \\
\hline
\end{tabular}

*, ** significant at 0.05 and 0.01 respectively. INT is the Interest rate,

MS is the Money Supply, INF is the Inflation rate, GDP is the Gross

Domestic Product of Jordan, NAPS is the Net Asset Value per Share, DPR

is the Dividend payout ratio and EPS is the Earnings per Share.

negative impact of inflation on the movements of stock prices is consistent with (Zhao, 1999 \& Udegbunam and Eriki, 2001) studies which concluded the existence of adverse impact of the inflation on stock prices. The negative effect of the interest rate on the stock prices is also consistent with (Al-Qenae, Li \& Wearing ,2002, and Mukherjee and Naka, 1995) studies which have proved that there is a negative impact of interest rates on the movements of stock prices. Also the positive impact of GDP and MS on the stock price movements in this study are consistent with (Ibrahim 2003; Mukherjee and Naka 1995; Chaudhuri and Smiles, 2004) 
and (Dimitrios Tsoukalas, 2003, Ibrahim, 2003 and Maysami and Koh, 2000) studies respectively.

\section{Conclusion}

The main objective of this study is to deliver empirical Jordanian evidence regarding the impact of macroeconomic factors on the movements of the Jordanian stock prices. The unbalanced pooled cross-sectional time series multiple least square regression method have been utilized to present data analysis, and the results of the study concluded that macroeconomic factors are significantly determinants of stock price movements in Jordan. This paper makes an empirical contribution to the continuing discussion on the impact of macroeconomic factors on stock price movements in developing countries' economies, and a theoretical contribution to the present literature. At the level of decision-making, these results can provide solutions that contribute to the revitalization and stabilization of financial markets.

\section{Acknowledgements}

The author is grateful to the Applied Science Private University, Amman, Jordan, for the financial support granted to this research project (Grant No. DRGS-2014-2015-211).

\section{References}

Aggarwal R (1981). Exchange Rates and Stock Prices: A Study of the U.S. Capital Markets under Floating Exchange Rates. Akron Bus. Econ Rev. 12, 7-12.

Al-Qenae, Rashid, Li, Carmen Wearing, Bob. (2002). The Information Content of Earnings on Stock Prices: The Kuwait Stock Exchange. Multinational Finance Journal, 6. http://dx.doi.org/10.17578/6-3/4-3

Asprem M. (1989). Stock Prices, Asset Portfolios and Macroeconomic Variables in Ten European Countries. J. Bank. Fin., 13, 589-612. http://dx.doi.org/10.1016/0378-4266(89)90032-0

Barrows CW, Naka A (1994). Use of Macroeconomic Variables to Evaluate Selected Hospitality Stock Returns in the U.S. Int. J. Hosp. Mgt., 13, 119-128. http://dx.doi.org/10.1016/0278-4319(94)90033-7

Booth JR, Booth LC. (1997). Economic Factors, Monetary Policy and Expected Returns on Stock and Bonds. Econ. Rev Fed. Res. Bank San Francisco, 2, 32-42.

Chaudhuri, K., \& Smiles, S. (2004). Stock Market and Aggregate Economic Activity: Evidence from Australia. Applied Financial Economics, 14. http://dx.doi.org/10.1080/0960310042000176399

Chen MH. (2003). Risk and Return: CAPM and CCAPM. Q. Rev. Econ. Fin., 43, 369-393. http://dx.doi.org/10.1016/S1062-9769(02)00125-4

Chen MH, Kim WG, \& Kim HJ. (2005). Macro and Non-Macro Explanatory Factors of Chinese Hotel Stock Returns. Int. J. Hosp. 243-258. 
Chen SJ, Roll F, \& Ross SA (1986). Economic Forces and the Stock Market. J. Bus., 59(3), 505-523. http://dx.doi.org/10.1086/296344

Cochrane, J. H. (1992). Explaining the variances of price-dividend-ratio. Review of Financial Status, 15, 243-286. http://dx.doi.org/10.1093/rfs/5.2.243

Corwin, Shane, A. (2003). The Determinants of Underpricing for Seasoned Equity Offers. Journal of Finance, 5(58). http://dx.doi.org/10.1111/1540-6261.00604

Dimitrios, Tsoukalas. (2003). Macroeconomic Factors and Stock Prices in the Emerging Cypriot Equity Market. Managerial Finance, 29(4), 87-92. http://dx.doi.org/10.1108/03074350310768300

Gompers, Paul A., Joy L. Ishii, \& Andrew Metrick. (2003). Corporate Governance and Equity Prices.

Guglielmo Maria C., Peter G. A. Howells, \& Alaa M. Soliman. (2004). Stock Market Development and Economic Growth: The Causal Linkage. Journal of Economic Development, 33(29).

Ibrahim, Mansor H. (1999). Macroeconomic Variables and Stock Prices in Malaysia: An Empirical Analysis. Asian Economic Journal, 13(2), 219-231. http://dx.doi.org/10.1080/1354786032000045228

Ibrahim, Mansor H. (2003). Macroeconomic Forces and Capital Market Integration: A VAR Analysis for Malaysia. Journal of the Asia Pacific Economy, 8(1), 19-40.

Koutoulas G, \& Kryzanowski L. (1996). Macro-factor Conditional Volatilities, Time-Varying Risk Premia and Stock Return Behavior. Financ. Rev., 31(1), 169-195. http://dx.doi.org/10.1111/j.1540-6288.1996.tb00869.x

Koutsoyiannis, A. (1977). Theory of Econometrics. New York: Palgrave Publishers Ltd.

Levine, R., \& Zervos, S. (1998). Stock markets, banks, and economic growth. American Economic Review, 88, 538-558.

Maysami, R. C., \& Koh, T. S. (2000). A Vector Error Correction Model of the Singapore Stock Market. International Review of Economic Finance. http://dx.doi.org/10.1016/S1059-0560(99)00042-8

Mukherjee, Tarun, \& Naka Atsujuki. (1995). Dynamic Relations between Macroeconomic Variables and the Japaness Stock Market: An Application of Vector Error Correction Model. The Journal of Financial Research, 18. http://dx.doi.org/10.1111/j.1475-6803.1995.tb00563.x

Schwert GW. (1989). Why does stock market volatility change over time? J. Financ. 44(5), 1115-1153. http://dx.doi.org/10.1111/j.1540-6261.1989.tb02647.x

Soenen L, \& Hennigar E (1988). An Analysis of Exchange Rates and Stock Prices: The US Experience (1980-1986). Akron Bus. Econ. Rev., 19(4),7-16. 


\section{Macrothink}

Asian Journal of Finance \& Accounting ISSN 1946-052X

Timmerman, A. (1995). Cointegration tests of present value models with a time- varying discount factor. Journal of Applied Econometrics, 10, 17-31. http://dx.doi.org/10.1002/jae.3950100103

Udegbunam, Ralph I., \& P. O. Eriki (2001). Inflation and Stock Price Behavior: Evidence from Nigerian Stock Market. Journal of Financial Management and Analysis, 14(1), 1-10.

Wohar, \& Mark, E. (2006). What drives stock prices? Identifying the determinants of stock price movements. Southern Economic Journal.

Wongbangpo P, \& Sharma SC (2002). Stock Market and Macroeconomic Fundamental Dynamic Interactions: ASEAN-5 Countries. J. Asian Econ., 13, 27-51. http://dx.doi.org/10.1016/S1049-0078(01)00111-7

Zhao, Xing-Qiu. (1999). Stock prices, inflation and output: evidence from China. Applied Economics Letters, 6. http://dx.doi.org/10.1080/135048599352835 